Research Article

\title{
Geographic mapping of head and neck cancers in Nanded, Maharashtra, India: A hospital based study
}

\author{
Namdhari $\mathrm{BH}^{1}$, Deshpande $\mathrm{SA}^{2}$ \\ ${ }^{1}$ Dr Balkrishna Harishchandrarao Namdhari, Associate Professor, ${ }^{2}$ Dr Shubha Arvind Deshpande, Professor and Head, all \\ authors are affiliated with Department of Pathology, Dr. Shankarrao Chavan Government Medical College, Nanded, \\ Maharashtra State, India
}

Address for Correspondence: Dr Balkrishna Harishchandrarao Namdhari, 213, Sanman Towers, 3-1-783 Vazirabad, Nanded, Maharashtra State, India. Email: namdhari@writeme.com

\begin{abstract}
Background: Head and neck cancers are most common in developing countries. It is the most common cancer of males in India and fifth in females. India is classified as a lower middle income group country by World Bank. Nanded, Maharashtra, India is a district place where this government medical college and hospital is situated; this is a tertiary medical care centre and caters nearby districts like Parbhani, Hingoli, Yavatmal and Adilabad. Methods: This is cross sectional study of 18 months. Cases are selected with superficially palpable head and neck lesions referred to Cytology OPD, and hospital ward with clinical diagnosis of any head and neck neoplastic lesions. An FNAC smear in the Cytology section of CCL and in ward finally the microscopic verification is done by biopsies with histopathological confirmation is done and confirmed cases are included in this study. Geographical mapping done by making the master chart of patient's permanent addresses. Patients categorized as per codes by NCRP used for Atlas of cancer of India. Results: Relative proportion percentage of head and neck cancers is 88.33 were from Nanded district, followed by Hingoli, Parbhani, Yavatmal from Maharashtra state and Adilabad districts from Telangana state. Conclusions: This centre caters more than five districts including Maharashtra and Telangana state, in this hospital based 'head and neck cancer registry' of microscopically confirmed cancers, maximum cases are from Nanded district. This institute does not cover the geographic area mentioned in the literature of highest and lowest relative proportion percentage of head and neck cancers.
\end{abstract}

Key words: Cancer Registry, District Data, Geographic Pathology, Head and Neck Cancers.

\section{Introduction}

Head and neck cancers form only $1-4 \%$ of all cancers in the western world and are common cancers in South and East Asian countries. Oral cancers are most predominant form of head and neck squamous cell carcinomas in India, Pakistan, and South East Asian countries. Oropharyngeal and tongue cancers are common in western world. Head and neck cancers are most common cancers in developing countries. It is most common cancer of males in India and fifth in females [1].

Europe and United States of America reports of head and neck cancers are increasing among the young particularly in tongue. Oral cancers formed the majority

Manuscript received: $12^{\text {th }}$ September 2016

Reviewed: $25^{\text {th }}$ September 2016

Author Corrected: $10^{\text {th }}$ October 2016

Accepted for Publication: $25^{\text {th }}$ October 2016 of head and neck cancers with predilection for tongue except in rural males in whom pharynx was predominant sub site. Incidence of head and neck squamous cell carcinomas are reducing and is attributed to decrease in the prevalence of tobacco use. The increase in incidence of tongue cancers may suggest factors other than tobacco and alcohol in genesis [2].

India is classified as a lower middle income group country by World Bank. Ninety per cent of oral cancer patients in rural India belong to the lower middle socioeconomic class and $36 \%$ are below poverty line. Indian Council of Medical Research has shown the incidence of various cancers in different parts of India (Table 1) [1], a pan India study of microscopically diagnosed cancers in 2001-2002 from 68 districts across 
Research Article

India shown in (Table. 2) [4]. PBCR data shows MAAR is the highest for following topography sites (Table 3 ).

Nanded, Maharashtra, India is a district place where this government medical college and hospital is situated, this is a tertiary medical care centre, and this centre caters nearby districts like Parbhani, Hingoli, Yavatmal from Maharashtra state and Adilabad district from Telangana state. Nanded city is situated on the river side of Godavari is also called as 'dakshin ganga' previously it was a part of Nizam State.

Now this district is a part of Marathwada division of Maharashtra state of India. There is a famous Gurdwara of the $10^{\text {th }}$ Guru of Sikh religion Shree Guru Gobind Singh Ji.

\section{Methods}

This is a tertiary care and the referral centre caters more than five districts including Maharashtra and Telangana state, as this activity belongs to hospital based head and neck cancer registry of microscopically confirmed cancers which are having highest accuracy of diagnosis.

The present study was undertaken in the department of Pathology, Government Medical College and Hospital, Nanded, India which is a leading histopathology laboratory in the city.

This is a prospective \& cross-sectional study over the period of 18 months from January 2008 to June 2009. The inclusion criteria were as below.
1. Sample collection method was the patients collection presented with superficially palpable head and neck lesion referred to cytology OPD.

2. Also samples of patient's admitted in hospital ward of this institute with clinical diagnosis of any head and neck neoplastic lesions.

3. Above selected patients with head and neck lesions the FNAC smears were taken and cytologically positive patients referred for biopsy procedures.

4. Microscopic verification done by biopsy histopathology examination (HPE) so in this way the histopathological confirmation done on cytologically suspected cases for malignancies. These confirmed cases were included in present study.

5. Exclusion criteria were dropping the benign tumors and tumor like lesions from the Head and Neck Neoplastic Lesions.

Thus remaining the head and neck cancer cancers were included for geographical mapping, in which their permanent addresses are categorized as per codes mentioned in the reference quoted as similar type of study conducted by NCRP for Atlas of cancer of India [4]. All these cases in specified period were studied prospectively in the department of Pathology, Government Medical College and Hospital, Nanded, Maharashtra, India. Statistical method used was the district wise mapping done by calculating percentage of head and neck cancers in the hospital catering the districts in the Maharashtra state and nearby Telangana state.

\section{Results}

In the present study, the geographic mapping of cases of histopathologically confirmed head and neck malignancy was done, the maximum number of cases of head and neck cancers were from Nanded district (88.33\%) followed by Hingoli, Parbhani,Yavatmal and Adilabad districts (Table 4).

Table-1: Incidence of head and neck cancers in Indian scenario.

\begin{tabular}{|c|c|c|c|c|c|c|c|}
\hline $\begin{array}{c}\text { Serial } \\
\text { Number }\end{array}$ & District & State & $\begin{array}{l}\text { Portion } \\
\text { Of India }\end{array}$ & $\begin{array}{l}\text { Site } \\
\text { Involving } \\
\text { cancer }\end{array}$ & Sex & $\begin{array}{l}\text { Incidence per } \\
100000 \\
\text { population }\end{array}$ & Remarks \\
\hline 1 & \multirow[t]{2}{*}{ Aizawl } & \multirow[t]{2}{*}{ Mizoram } & \multirow[t]{3}{*}{$\begin{array}{l}\text { North } \\
\text { East }\end{array}$} & $\begin{array}{l}\text { Lower } \\
\text { Pharynx }\end{array}$ & Men & 11.5 & $\begin{array}{l}\text { World's highest } \\
\text { incidence }\end{array}$ \\
\hline 2 & & & & Tongue & Men & 07.6 & Highest incidence \\
\hline 3 & Kohima & Nagaland & & Nasophary! & cance & & $\begin{array}{ll}\text { World's } & \text { highest } \\
\text { incidence } & \end{array}$ \\
\hline
\end{tabular}


Table-2: Head and Neck cancers, highest incidence Geographical locations 2001-02 [4].

\begin{tabular}{|c|c|c|c|}
\hline Serial Number & States & Portion of India & Sex- Cancer Site \\
\hline 1 & \multirow{2}{*}{$\begin{array}{l}\text { Aizawl } \\
\text { Mizoram }\end{array}$} & \multirow[b]{4}{*}{ North East India } & Males-Lower Pharynx \\
\hline 2 & & & Males-Tongue \\
\hline 3 & $\begin{array}{l}\text { Kohima } \\
\text { Nagaland }\end{array}$ & & \multirow[b]{2}{*}{ Males-Nasopharyngeal Cancers } \\
\hline 4 & $\begin{array}{l}\text { Imphal } \\
\text { Manipur }\end{array}$ & & \\
\hline 5 & $\begin{array}{l}\text { Karnataka } \\
\text { Tamil Nadu } \\
\text { Kerala }\end{array}$ & Southern States in India & Males and Females-Mouth \\
\hline 6 & $\begin{array}{l}\text { Gujarat } \\
\text { Goa } \\
\text { Karnataka } \\
\text { Kerala } \\
\text { Sikkim } \\
\text { Nagaland } \\
\text { Manipur }\end{array}$ & $\begin{array}{l}\text { South west coastal districts and } \\
\text { North East India }\end{array}$ & Females-Thyroid cancers \\
\hline
\end{tabular}

Table-3: Leading Topographic sites in the region of Head and Neck cancers Population Based Cancer Registry Data [3].

\begin{tabular}{|c|l|l|l|l|}
\hline Sr No & Topographic sites as per ICD 10 & Per100000 population & Gender & PBCR \\
\hline 1 & Tongue C01-C02 & 10.0 & \multirow{2}{*}{ Males } & \multirow{2}{*}{ Bhopal } \\
\cline { 1 - 3 } 2 & Mouth C03-C06 & 08.6 & & \\
\hline 3 & Naso pharynx C11 & 00.7 & Females & Bengaluru \\
\hline
\end{tabular}

Table-4: Geographic Mapping (district wise distribution) of Head and Neck cancers in histopathologically confirmed cases showing relative proportion percentage of cases [6].

\begin{tabular}{|c|l|l|l|l|l|}
\hline Sr No. & District & State & Geographic Area Code & Number & $\%$ \\
\hline 1 & Nanded & & 2715 & 53 & 88.33 \\
\cline { 5 - 6 }$n$ & \multirow{4}{*}{ Maharashtra State } & 2716 & 02 & 03.33 \\
\hline 3 & & 2717 & 02 & 03.33 \\
\hline 4 & Parbhani & 2714 & 02 & 03.33 \\
\hline 5 & Yavatmal & & 2801 & 01 & 01.68 \\
\hline 6 & Adilabad & Telangana State & 60 & 100.0 \\
\hline
\end{tabular}

Table-5: Comparison of cancer cases in present study and previous study at the same institute [5].

\begin{tabular}{|c|c|c|c|c|c|}
\hline $\begin{array}{l}\text { Sr } \\
\text { No. }\end{array}$ & District. & State. & $\begin{array}{l}\text { Geographic } \\
\text { Area code. }\end{array}$ & $\begin{array}{l}\text { 'All Cancers' number } \\
\text { in percentage in } \\
\text { previous study. } \\
2001-2002 \text { [5]. }\end{array}$ & $\begin{array}{l}\text { 'Head and Neck } \\
\text { Cancers' percentage } \\
\text { in present study } \\
2008-2009 .\end{array}$ \\
\hline 1 & Nanded & \multirow[t]{4}{*}{ Maharashtra } & 2715 & 78.7 & 88.33 \\
\hline 2 & Hingoli & & 2716 & 06.7 & 03.33 \\
\hline 3 & Parbhani & & 2717 & 04.7 & 03.33 \\
\hline 4 & Yavatmal & & 2714 & 04.1 & 03.33 \\
\hline 5 & Adilabad & Telangana & 2801 & 01.4 & 01.68 \\
\hline 6 & \multicolumn{2}{|l|}{ Other Districts } & - & 04.5 & 00.00 \\
\hline 7 & TOTAL & \multicolumn{2}{|c|}{ Hospital Based Cancer Registry } & 100.0 & 100.0 \\
\hline
\end{tabular}


Research Article

Table-6: Comparisons of Head and Neck cancer geographic mapping in India and Internationally by AAR [4].

\begin{tabular}{|c|c|c|c|c|c|c|c|c|}
\hline \multirow{3}{*}{ 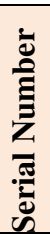 } & \multirow{3}{*}{ 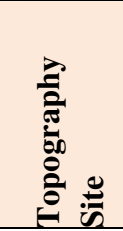 } & \multirow[b]{3}{*}{ : } & \multicolumn{4}{|l|}{ INDIAN } & \multirow{2}{*}{\multicolumn{2}{|c|}{$\begin{array}{l}\text { All World PBCR } \\
\text { Internationally }\end{array}$}} \\
\hline & & & \multicolumn{2}{|l|}{ PBCR } & \multicolumn{2}{|l|}{ Districts } & & \\
\hline & & & 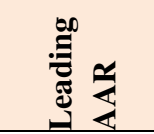 & 离 & 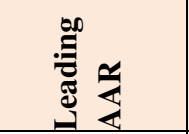 & 苞范 & 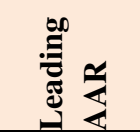 & 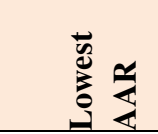 \\
\hline 1 & Tongue & Male & \multirow{4}{*}{ Bhopal } & \multirow{4}{*}{ Barshi } & $\begin{array}{l}\text { Aizawl } \\
\text { MZ }\end{array}$ & $\begin{array}{l}\text { Imphal West } \\
\text { MR }\end{array}$ & \multirow{2}{*}{$\begin{array}{l}\text { Bhopal } \\
\text { India }\end{array}$} & $\begin{array}{l}\text { Qi. County } \\
\text { China }\end{array}$ \\
\hline 2 & Mouth & Male & & & $\begin{array}{l}\text { Wardha } \\
\text { MH }\end{array}$ & $\begin{array}{l}\text { Bhavnagar } \\
\text { GJ }\end{array}$ & & $\begin{array}{l}\text { Singapore } \\
\text { Malay }\end{array}$ \\
\hline 3 & Mouth & 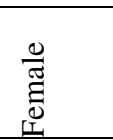 & & & $\begin{array}{l}\text { Kolar } \\
\text { KA }\end{array}$ & $\begin{array}{l}\text { Thrissur } \\
\text { KL }\end{array}$ & $\begin{array}{l}\text { Pakistan } \\
\text { South } \\
\text { Karachi }\end{array}$ & $\begin{array}{l}\text { Qi. County } \\
\text { China }\end{array}$ \\
\hline 4 & Tonsil & Male & & & $\begin{array}{l}\text { Darrang } \\
\text { AS }\end{array}$ & $\begin{array}{l}\text { Kancheepuram } \\
\text { TN }\end{array}$ & \multirow[b]{2}{*}{$\begin{array}{l}\text { Calvados } \\
\text { France }\end{array}$} & $\begin{array}{l}\text { Algiers } \\
\text { Algeria }\end{array}$ \\
\hline 5 & $\begin{array}{l}\text { Oro } \\
\text { pharynx }\end{array}$ & Male & Bengaluru & \multirow[b]{2}{*}{ Mumbai } & $\begin{array}{l}\text { Barpeta } \\
\text { AS }\end{array}$ & $\begin{array}{l}\text { Dakshin } \\
\text { Kannada } \\
\text { KA }\end{array}$ & & Costa Rica \\
\hline 6 & $\begin{array}{l}\text { Naso } \\
\text { pharynx }\end{array}$ & Male & Chennai & & $\begin{array}{l}\text { Kohima } \\
\text { NL }\end{array}$ & $\begin{array}{l}\text { Thane } \\
\text { MH }\end{array}$ & $\begin{array}{l}\text { Hong } \\
\text { Kong } \\
\text { China }\end{array}$ & $\begin{array}{l}\text { Quito } \\
\text { Equador }\end{array}$ \\
\hline 7 & $\begin{array}{l}\text { Hypo } \\
\text { pharynx }\end{array}$ & Male & Bhopal & Delhi & $\begin{array}{l}\text { Aizawl } \\
\text { MZ }\end{array}$ & $\begin{array}{l}\text { Chamrajnagar } \\
\text { KA }\end{array}$ & $\begin{array}{l}\text { Bas-Rhin } \\
\text { Fran. }\end{array}$ & $\begin{array}{l}\text { Bamako } \\
\text { Mali }\end{array}$ \\
\hline 8 & Pharynx & Male & Mumbai & Chennai & $\begin{array}{l}\text { Anand } \\
\text { GJ }\end{array}$ & $\begin{array}{l}\text { Vadodara } \\
\text { GJ }\end{array}$ & $\begin{array}{l}\text { Somme } \\
\text { France }\end{array}$ & $\begin{array}{l}\text { Algiers } \\
\text { Algeria }\end{array}$ \\
\hline 9 & Larynx & Male & Delhi & \multirow[b]{2}{*}{ Barshi } & $\begin{array}{l}\text { Imphal West } \\
\text { MR }\end{array}$ & $\begin{array}{l}\text { Villupuram } \\
\text { TN }\end{array}$ & $\begin{array}{l}\text { Spain } \\
\text { Zaragoza }\end{array}$ & $\begin{array}{l}\text { The } \\
\text { Gambia }\end{array}$ \\
\hline 10 & Thyroid & Female & Bengaluru & & $\begin{array}{l}\text { Imphal East } \\
\text { MR }\end{array}$ & $\begin{array}{l}\text { East Godavari } \\
\text { AP }\end{array}$ & $\begin{array}{l}\text { USA } \\
\text { Filipino }\end{array}$ & $\begin{array}{l}\text { Qi. County } \\
\text { China }\end{array}$ \\
\hline
\end{tabular}

\section{Discussion}

When compared with geographical data of same institute data of 'all cancers' is somewhat comparable [4]. The cases of head and neck cancers are more than all other cancers hence it may be stated that the incidence of head and neck cancers may be more than Nanded district, it may be emergence of head and neck cancers in Adilabad district of Telangana state in recent years .The data of head and neck cancers in the previous study is not available while the data of all cancers is available in relation with the same geographical area (Table 5).

In 82 districts pan India study of 2001-2002 highlights some topographic sites with gender showing highest incidence of geographical locations in India and internationally are in (Table 6) [4].

Bhopal, Bengaluru, Chennai, Mumbai and Delhi PBCR data is showing the highest incidence of head and neck cancers in which, Bhopal covers maximum topographic sites in the region of head and neck include MalesTongue, Males-Mouth, Males-Tonsil and Males-hypo pharynx, Females-Mouth, Bengaluru PBCR covers Male-Oropharynx Females-Thyroid, Chennai PBCR covers Males- Naso pharynx, Mumbai PBCR covers Males-Pharynx and Delhi PBCR covers Males-Larynx.

Internationally Bhopal PBCR is having highest incidence in the world in the topographic sites of MaleTongue and Male-Mouth [4].

District wise data shows highest incidence in India, Aizawl MZ shows the topographic site Males-Tongue, and Male-Hypo pharynx, Imphal west MR the site is Male-Larynx, Imphal east MR the site is FemaleThyroid, Anand GJ the site is Male-Pharynx, Kohima NL the site is Male-Naso Pharynx, Barpeta AS the site is Male-Oropharynx, Darrang AS the site is MaleTonsil, Kolar KA Female-Mouth and Wardha MH the site is Male- Mouth [4]. 
Research Article

\section{Conclusions}

This tertiary care referral centre caters more than five districts including Maharashtra and Telangana state, as this activity belongs to hospital based head and neck cancer registry of microscopically confirmed cancers which is having highest accuracy of diagnosis and maximum cases are from Nanded district of Maharashtra state which is followed by Hingoli district. Very small population of Telangana state by this tertiary care centre is covered. This institute does not cover any geographic area mentioned in the literature of highest and lowest proportion percentage of head and neck cancers [4] [6].

Acknowledgements: I sincerely express my thanks to my post graduate student Dr Amit U. Maniyar Green Cross Path Lab Ahmadabad who has created such data for his dissertation for M.D. (Pathology) (MUHS) (2010) and also express my thanks to $\operatorname{Dr} \mathrm{A}$. Nandakumar, NCRP Bengaluru, India, who has created 'An Atlas of Cancer of India' with the support of World Health Organization from whom I received an inspiration for this project.

\author{
Abbreviations \\ AAR : Age Adjusted Rate/100000 \\ CCL : Central Clinical Laboratory \\ FNAC : Fine Needle Aspiration Cytology \\ MAAR : Microscopic Age Adjusted Rate/100000 \\ NCRP : National Cancer Registry Program \\ OPD : Out Patient Department \\ PBCR : Population Based Cancer Registry \\ WHO : World Health Organization
}

\section{Declarations}

Funding: Nil, Conflict of interest: None initiated, Permission from IRB: Yes

\section{Bibliography}

1. Joshi P, Dutta S, Chaturvedi P, Nair S. Head and neck cancers in developing countries, Rambam Maimonides Med J 2014; 5(2). e0009.doi: 10.5041/ RMMJ.10143.

2. Elango JK, Gangadharan P, Sumithra S, Kuriakose MA. Trends of head and neck cancers in urban and rural India, Asian Pac J Cancer Prev.2006;7,108-112.

3. Nandkumar A, Gupta PC, Gangadharan P, Visweswara RN, Parkin DM. Geographic pathology revisited: development of an atlas of cancer in India. Int J Cancer. 2005 Sep 20; 116 (5) : 740-54. DOI:10. 1002/ ijc.21109.

4. Nandakumar A, Gupta PC, Gangadharan, Visweswara RN. Development of an atlas of cancer in India, A project of the national cancer registry programme (Indian council of medical research) supported by World Health Organization, First all India report : 2001-2002 Mapping patterns of cancer, Information technology in medicine-Measuring burden of disease, Volume I, Bengaluru, India: National Cancer Registry Programme (ICMR); 2004.

5. Nandakumar A, Gupta PC, Gangadharan, Visweswara RN. Development of an atlas of cancer in India, A project of the national cancer registry programme (Indian council of medical research) supported by World Health Organization, First all India report: 2001-2002 Mapping patterns of cancer, Information technology in medicine-Measuring burden of disease, Volume II, Bengaluru, India: National Cancer Registry Programme (ICMR); 2004.

6. Maniyar AU, Study of cytodiagnosis of head and neck neoplastic lesions and mapping patterns of head and neck cancers [MD thesis], Nanded: Maharashtra University of Health Sciences, Nashik, India; 2010.

\section{How to cite this article?}

Namdhari BH, Deshpande SA. Geographic mapping of head and neck cancers in Nanded, Maharashtra, India: A hospital based study.Trop J Path Micro 2016;2(3):99-103.doi: 10.17511/jopm.2016.i03.04 